\title{
ВНУТРІШНІ ПЕРЕДУМОВИ ФОРМУВАННЯ ЕКОНОМІЧНОЇ БЕЗПЕКИ ПІДПРИЕМСТВ МАШИНОБУДУВАННЯ
}

\section{INTERNAL CONDITIONS OF FORMING ECONOMIC SAFETY OF MACHINE- BUILDING ENTERPRISES}

У статті розглянуто внутрішні передумови формування економічної безпеки підприємств машинобудування. Встановлено, що умови функціонування підприємств машинобудівної галузі, які існують сьогодні, обумовлені високим ступенем нестабільності та нестійкості, через вплив загальносвітової економічної кризи. Однією з найважслиіших проблем, щзо стоять перед вітчизняною економікою, $\epsilon$ забезпечення стабільного економічного зростання не лише у сировинних галузях, але, перш за все, у провідних галузях промислового комплексу, центром тяжіння якого виступає машинобудівна галузь. Саме машинобудування визначає сочіально-економічний і техніко-технологічний рівень розвитку держави, конкурентоспроможність його виробництв. Для сучасних украйнських машинобудівних підприємств важливим є ефективне функціонування та підтримання на високому рівні конкурентоспроможності, щэо забезпечить належний рівень його економічної безпеки.

Встановлено, щзо критично високий темп падіння машинобудування негативно впливає на темпи розвитку національної економіки, оскільки вони забезпечують ї конкурентоспроможність на зовнішньому ринку та стабілізують внутрішні процеси шляхом використання значної частки працездатного населення.

У статті проаналізовано становище галузі в розрізі основних структурних складових економічної безпеки для визначення безпечності стану діяльності машинобудівних підприємств України. Обтрунтовано, що найвідчутнішим фактором впливу на фінансові результати промислових підприємств була фінансова криза. 3 метою оцінювання рівня прибутковості підприємств машинобудівної промисловості досліджено динаміку показників рентабельності операчійної діяльності підприємств машинобудування.

В результаті проведеного аналізу внутрішніх передумов формуванні економічної безпеки підприємств машинобудування встановлено, що рівень фінансової безпеки галузі $\epsilon$ низьким та потребує змін. Отже, розвиток машинобудівних підприємств супроводжується накопиченням проблем, які негативно на них впливають. Під дією різних факторів розвиток машинобудівної галузі відбувається не прогнозовано, не за планами $i$ програмами, що формуються урядами з урахуванням потреб у промисловій продукції й вимог глобалізації світової економіки. Ситуація погіршується із зменшенням проміжків часу між світовими кризами, які негативно впливають на стан національної економіки Украӥни.

Ключові слова: машинобудування, економічна безпека, фінансові результати, експорт, імпорт, основні засоби, інноваційна діяльність. 
The internal prerequisites of formation of economic safety of mechanical engineering enterprises are considered in the article. It is established that the conditions of functioning of the machine-building industry enterprises, which exist today, are caused by a high degree of instability, because of the influence of the global economic crisis. One of the most important problem facing the domestic economy is to ensure stable economic growth not only in the raw materials industries, but first of all in the leading industries of the industrial complex, whose center of gravity is the machine-building industry. The engineering determines the socioeconomic and technological level of state development, the competitiveness of its productions. Efficient functioning and maintenance of a high level of competitiveness, which will ensure the proper level of its economic safety, is important for modern Ukrainian machine-building enterprises.

It has been established that the critically high rate of decline in machine building negatively affects the pace of development of the national economy, since it ensures its competitiveness in the foreign market and stabilizes internal processes by using a significant part of the able-bodied population.

The article analyzes the situation of the industry in the context of the main structural components of economic safety in order to determine the safety of the state of activity of the machine-building enterprises in Ukraine. It is substantiated that financial crisis was the most sensitive factor influencing thefinancial results of industrial enterprises. In order to assess the level of profitability of the enterprises of the machine-building industry, the dynamics of profitability indicators of operating activity of mechanical engineering enterprises is researched.

As a result of the analysis of internal prerequisites for the formation of economic safety of the enterprises of mechanical engineering, it was established that the level of financial security of the industry is low and needs to be changed. Consequently, the development of machine-building enterprises is accompanied by the accumulation of problems that negatively affect them. Under the influence of various factors, the development of the machine-building industry is not predictable, not by plans and programs, which are formed by governments, nor taking into account the needs of industrial products and the requirements of globalization of the world economy. The situation is getting worsewith a decreases in the time spans between global crises, which adversely affects the state of the national economy of Ukraine.

Key words: machine building, economic security, financial results, export, import, fixed assets, innovative activity.

Вступ. Умови функціонування підприємств машинобудівної галузі, які існують сьогодні, обумовлені високим ступенем нестабільності та нестійкості, через вплив загальносвітової економічної кризи. Це викликає загальне зниження рівня економічної безпеки машинобудівних підприємств, а також можливості забезпечення їх сталого розвитку [1]. Машинобудівним підприємствам постійно доводиться приймати рішення щодо виживання та їх захисту від впливу дестабілізаційних факторів. Цих факторів є досить багато і всі вони впливають на підприємство по-різному. Власники та керівники машинобудівних підприємств змушені адаптуватись до виникнення цих негативних явищ та вживати заходів щодо їх упередження, знешкодження або нейтралізації. На сьогоднішній день сектор машинобудування стикнувся із рядом проблем, перш за все через геополітичні зміни в зовнішньому 
середовищі. В умовах постійного зростання конкуренції на світових ринках, національна галузь машинобудування опинилась перед викликами стратегічного характеру. Також існує ще безліч зовнішніх та внутрішніх чинників, які мають негативний вплив на машинобудування та потребують дослідження [5].

Завдання статті полягає в аналізі показників стану машинобудівної галузі України на предмет дотримання економічної безпеки.

Методологія. Теоретико-методологічною основою проведеного дослідження стали загальнонаукові методи наукового пізнання: монографічний, теоретичного узагальнення, систематизації, аналізу та синтезу.

Результати досліджень. Однією з найважливіших проблем, що стоять перед вітчизняною економікою, є забезпечення стабільного економічного зростання не лише у сировинних галузях, але, перш за все, у провідних галузях промислового комплексу, центром тяжіння якого виступає машинобудівна галузь.

Машинобудівний комплекс - один із провідних у промисловості України, який об'єднує систему науково-дослідних, конструкторськотехнологічних організацій; охоплює 11267 підприємств, з яких 146 - великих, 1834 - середніх та 9287 - малих; понад $22 \%$ зайнятого промислововиробничого персоналу, 13,4\% загального обсягу промислової продукції та понад 15\% вартості основних виробничих фондів [1].

Саме машинобудування визначає соціально-економічний i технікотехнологічний рівень розвитку держави, конкурентоспроможність його виробництв. Для сучасних українських машинобудівних підприємств важливим $\epsilon$ ефективне функціонування та підтримання на високому рівні конкурентоспроможності, що забезпечить належний рівень його економічної безпеки. А тому, проаналізуємо стан машинобудівної галузі за структурними складовими економічної безпеки за період 2012-2016 років на основі офіційної статистичної інформації.

У структурі машинобудування 2016 року найбільшу частку займало виробництво транспортних засобів та устаткування - 45\%, тоді як інші два сегменти - електричного, електронного й оптичного устаткування, 3 одного боку, і машин та устаткування - 3 другого, охоплюють відповідно 24\% і $31 \%$ (рис. 1) [2]. 


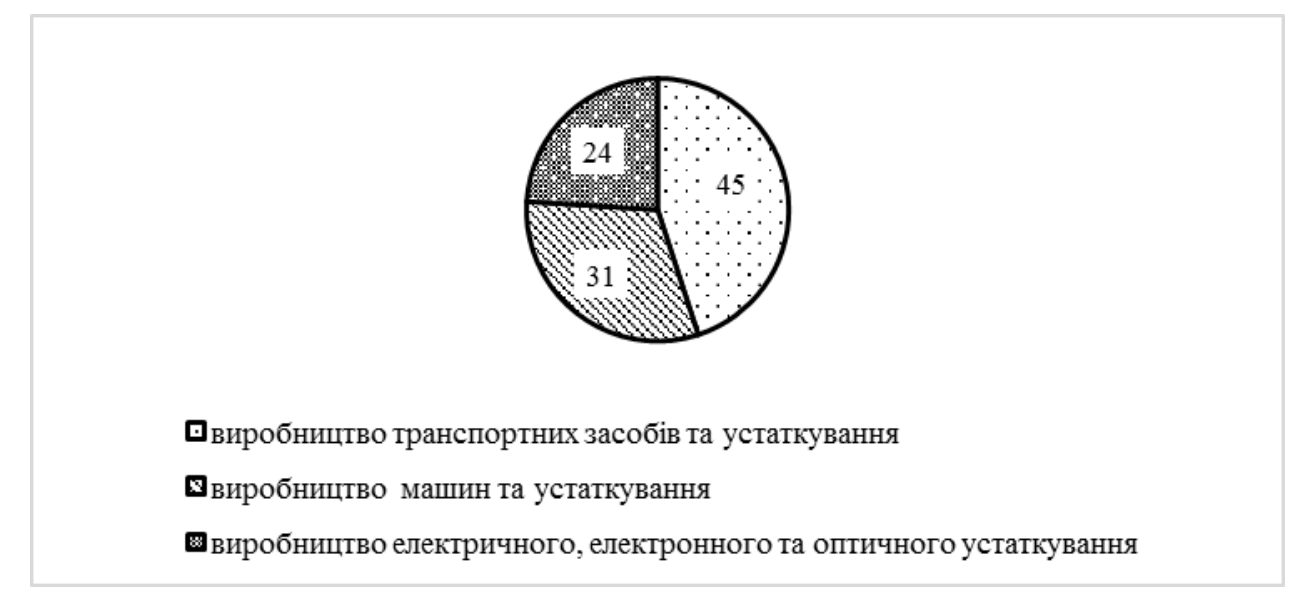

Рисунок 1 - Структура реалізованої продукції машинобудування y 2016 p., [2]

Для промисловості починаючи з 2011 по 2015 роки було характерне зниження темпів зростання обсягів виробництва відповідно: 108\%; 99,5\%; $95,7 \% ; 89,9 \% ; 87 \%$ (рис. 2.). Аналогічні тенденції були притаманні і для машинобудування: 115,9\%; 96,7 \%; 86,8\%; 79,4\%; 85,9\%; в 2016 році відбулось зростання до позначки $102 \%$, проте в 2016 році знову падіння до 99 \%. Потрібно підкреслити, що темпи зниження обсягів виробництва у 2014 р. у порівнянні із 2013 р. для машинобудівних підприємств були критично високими - 13,2\%. Для порівняння, більше падіння у зазначеному періоді мало місце лише стосовно виробництва хімічних речовин і хімічної продукції - 16,9\%. Варто зазначити, що критично високий темп падіння машинобудування та хімічного виробництва негативно впливає на темпи розвитку національної економіки, оскільки вони забезпечують іiі конкурентоспроможність на зовнішньому ринку та стабілізують внутрішні процеси шляхом використання значної частки працездатного населення [3].

Важливим кроком на шляху розбудови інноваційної економіки та інноваційної інфраструктури стало затвердження середньострокових пріоритетних напрямів інноваційної діяльності загальнодержавного рівня на 2017-2021 pp., де визначено найважливіші вектори високотехнологічного розвитку України, зокрема, у галузях машинобудування, АПК, фармацевтики та медичного обслуговування, а також природоохоронних, ресурсозберігаючих, інформаційних та нанотехнологій [4]. 


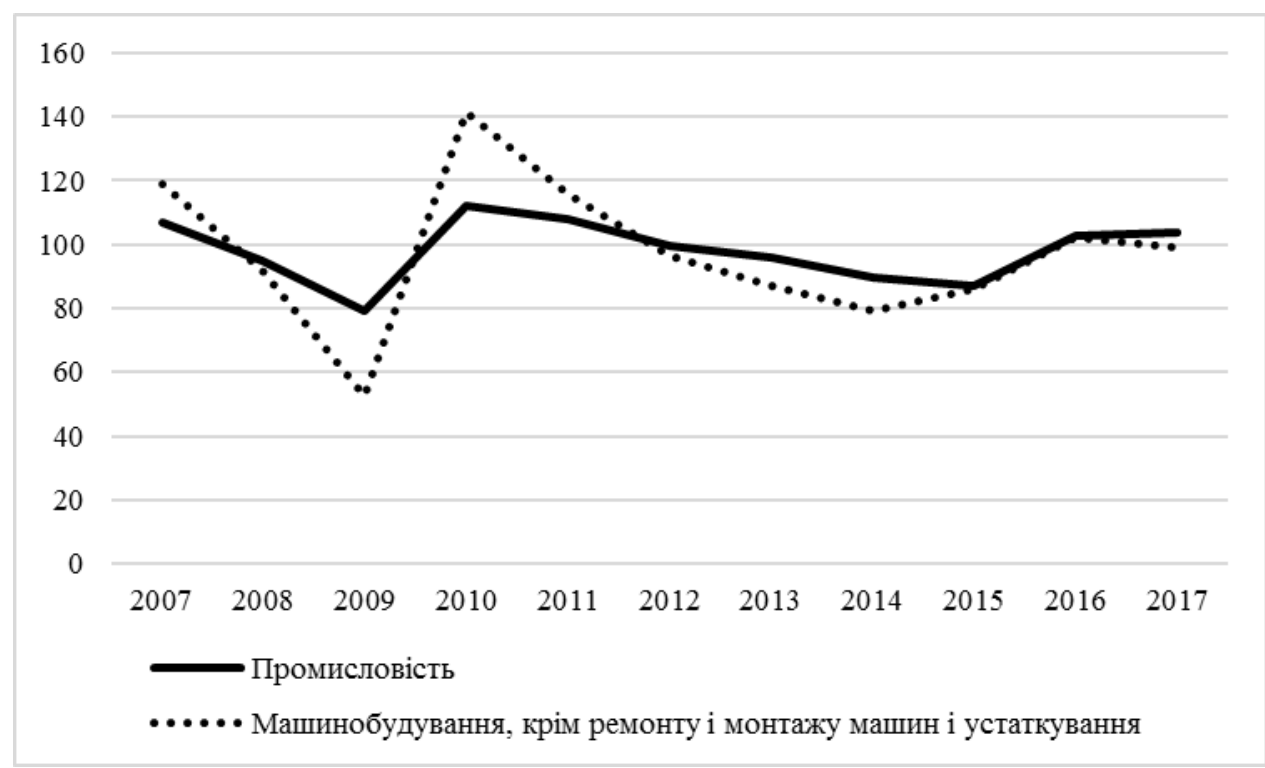

Рисунок 2 - Індекс промислової продукції України за $2007-2017$ pp., \%, [3]

Проаналізуємо становище галузі в розрізі основних структурних складових економічної безпеки для визначення безпечності стану діяльності машинобудівних підприємств України [5].

Для початку розрахуємо рівень фінансової безпеки машинобудівної галузі. Аналізуючи діяльність машинобудівних підприємств за обсягами реалізованої продукції та отриманими фінансовими результатами (табл. 1), слід відзначити, що загальний обсяг реалізованої продукції сnадає. Темпи його спадання в розрахунку до попереднього року збільшуються і становлять відповідно: $\mathrm{T}_{2011}=1,19 ; \mathrm{T}_{2012}=1,11 ; \mathrm{T}_{2013}=1,36 ; \mathrm{T}_{2014}=1,28 ; \mathrm{T}_{2015}=1,07 ; \mathrm{T}_{2016}=1,12$, $\mathrm{T}_{2017}=1,14$.

Таблиця 1 - Порівняльні фінансові результати діяльності промислових підприємств за період 2005-2017рр., [2; 3]

\begin{tabular}{|c|c|c|c|c|}
\hline \multirow{2}{*}{ Рік } & \multicolumn{2}{|c|}{$\begin{array}{c}\text { Чистий прибуток (збиток), } \\
\text { млн. грн. }\end{array}$} & \multicolumn{2}{c|}{$\begin{array}{c}\text { Кількість підприсмств до } \\
\text { загальної кількості, \% }\end{array}$} \\
\cline { 2 - 5 } & промисловість & машинобудування & промисловість & машинобудування \\
\hline 2005 & 17502,4 & 1258,4 & 62,4 & 65,3 \\
\hline 2006 & 22630,1 & 825 & 64,2 & 65,2 \\
\hline 2007 & 29286,9 & 3485,5 & 65,5 & 67,5 \\
\hline
\end{tabular}


Продовження табл. 1.

\begin{tabular}{|l|c|c|c|c|}
\hline 2008 & 5542,5 & $-1089,5$ & 59,6 & 62,0 \\
\hline 2009 & $-14192,5$ & 37,3 & 58,5 & 59,1 \\
\hline 2010 & 11889,6 & 4235,5 & 57,5 & 60,4 \\
\hline 2011 & 32229,9 & 10777,9 & 60,8 & 65,6 \\
\hline 2012 & 2592,4 & 9268,8 & 60,7 & 65,2 \\
\hline 2013 & $-4535,2$ & 3046,8 & 62,1 & 64,1 \\
\hline 2014 & $-4181,1$ & 2768,6 & 63,3 & 65,2 \\
\hline 2015 & $-188267,9$ & $-15374,0$ & 72,6 & 74,0 \\
\hline 2016 & $-24724,7$ & $-732,2$ & 72,5 & 76,9 \\
\hline 2017 & 72065,5 & 5039,7 & 69,0 & 75,7 \\
\hline
\end{tabular}

Найвідчутнішим фактором впливу на фінансові результати промислових підприємств була фінансова криза. Так, у 2009 р. збитки цих підприємств досягли 4760,7 млн грн, а кількість прибуткових підприємств зменшилась до $40,3 \%$. Такі результати позначились і на показниках чистого збитку $-14192,5$ млн. Однак, починаючи з 2010 р., вдалось покращити фінансові результати й отримувати чистий прибуток (11889,6 млн грн у 2010, 32229,9 млн - 2011 та 2592,4 млн грн у 2012 рр.), збільшивши частку прибуткових підприємств із $57,5 \%$ до $60,7 \%$ [2].

2011 р. завершили зі збитком 40,8\% промислових підприємств України. Позитивний фінансовий результат (сальдо) підприємств промисловості за 2011 р. становив 65 млрд 656,3 млн грн проти 26 млрд 530,5 млн грн в 2010 р. [2].

Як видно із наведених даних, найбільш успішною діяльність підприємств машинобудівного комплексу була у 2011 р., коли загальний фінансовий результат склав 10,7 млрд грн, у попередніх періодах найкращого результату галузь досягла у 2007 р., у цей період фінансовий результат підприємств машинобудування від звичайної діяльності до оподаткування склав 5,128 млрд. грн. Хоча в машинобудуванні за підсумками 2011 p. фінансові результати були дещо кращими, ніж у промисловості загалом, оскільки кількість збиткових підприємств досягла лише 32,8 \%.

32013 і по 2016 рік показники погіршувались, i, у підсумку, чистий збиток підприємств промисловості досяг 24724,7 млн. грн. Якщо говорити про фінансові результати підприємств машинобудування, то, їх збитки у 2016 році досягли позначки - 732,2 млн грн.

Машинобудівні підприємства належать до матеріаломістких виробництв, продукція є складною, із значною кількістю деталей та вузлів, а тому має багатоцехову організаційну структуру, що обумовлює значні витрати на оплату праці, обслуговування обладнання тощо [6].

Аналіз даних наведених у таблиці 2 демонструє, що за період 2009-2016 років частка матеріальних витрат у загальній структурі операційних витрат 
постійно збільшується і у 2016 році склала 70,9\% від загальної кількості витрат.

Таблиця 2 - Структура витрат реалізованої продукції у машинобудівній галузі України $[2 ; 3 ; 4]$

\begin{tabular}{|c|c|c|c|c|c|c|}
\hline \multirow[t]{2}{*}{ Роки } & \multicolumn{5}{|c|}{ \% до загальної кількості витрат } & \multirow[b]{2}{*}{$\begin{array}{c}\text { Операційні } \\
\text { витрати на } \\
\text { одиницю } \\
\text { реалізованої } \\
\text { продукції } \\
\text { коп./грн. }\end{array}$} \\
\hline & $\begin{array}{c}\text { Матері } \\
\text { альні } \\
\text { витрати }\end{array}$ & $\begin{array}{c}\text { Аморти- } \\
\text { зація }\end{array}$ & $\begin{array}{c}\text { Витрати } \\
\text { на оплату } \\
\text { праці }\end{array}$ & $\begin{array}{c}\text { Відраху- } \\
\text { вання на } \\
\text { соціальні } \\
\text { заходи }\end{array}$ & $\begin{array}{c}\text { Інші } \\
\text { операці } \\
\text { йні } \\
\text { витрати }\end{array}$ & \\
\hline 2009 & 70,7 & 2,8 & 11,9 & 4,6 & 10,5 & 96,2 \\
\hline 2010 & 62,6 & 4,1 & 14,7 & 5,4 & 13,2 & 93,3 \\
\hline 2012 & 67,6 & 2,8 & 13,6 & 5,0 & 11,0 & 91,1 \\
\hline 2013 & 68,1 & 3,1 & 14,1 & 7,3 & 12,2 & 89,1 \\
\hline 2014 & 70,3 & 3,4 & 14,4 & 7,5 & 11,9 & 86,3 \\
\hline 2015 & 70,6 & 3,6 & 14,5 & 7,6 & 12,1 & 90,2 \\
\hline 2016 & 70,8 & 3,4 & 14,6 & 7,7 & 12,2 & 93,2 \\
\hline
\end{tabular}

Найбільшою частка матеріальних витрат була у 2016 році. Така ситуація викликана у першу чергу зміною цін на ресурси галузі.

Найбільш показовим є значення операційних витрат на одиницю реалізованої продукції. Із таблиці 2 видно, що за період, який аналізується, ситуація склалась критична: обсяг витрат зменшився, проте залишається значним, що свідчить про значну витратомісткість продукції машинобудування [7].

Аналізуючи дані, можна сказати, що амортизація зросла з 3,1\% до 3,5\%, що може отримати пояснення як покращення стану галузі та незначного зменшення застарілого обладнання. Тенденція збільшення витрат на оплату праці може також бути розцінена як позитив.

Оскільки динаміка зміни рентабельності підприємств $є$ одним із найвагоміших в оцінюванні ефективності функціонування підприємств будьякої сфери діяльності, ми вважаємо за необхідне ії проаналізувати. 3 метою оцінювання рівня прибутковості підприємств машинобудівної промисловості на рис. 3 представлено динаміку показника рентабельності операційної діяльності підприємств машинобудування.

Аналізуючи рис. 3, можна сказати, що рівень рентабельності машинобудівних підприємств протягом 2008 - 2012 рр. стабільно зростав, а потім стрімко падав. Вважаю, що такий різкий спад рентабельності машинобудування пов'язаний 3 нестабільною фінансово-економічною та політичною ситуацією. 


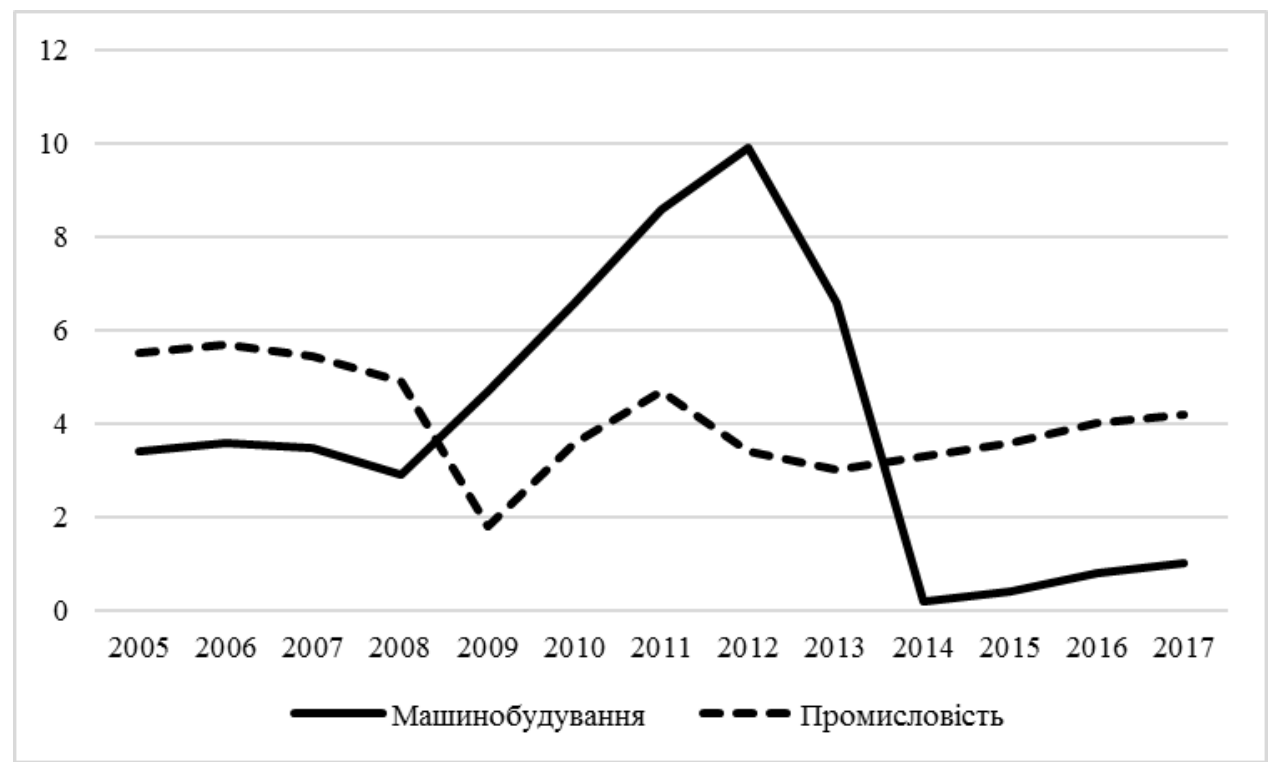

Рисунок 3 - Динаміка зміни рентабельності машинобудування України за 2005

$$
\text { - } 2017 \text { pp., \% [2; } 3]
$$

Найбільшого значення показник рентабельності сягнув 19,3 \% у 2012 році. За останні три роки показник падає, у 2015 році вже складає 10,3\%. Якщо говорити про імпорт, то з 2005 року по 2007 рік зростає з 26,5 \% до 32,6 $\%$, а потім падає до значення 19,4 \% у 2010 році, після чого зростає до значення $27 \% 2012$ року. Але знову падає і становить 16,7 \% у 2015 році. Про вищезазначене свідчать дані рисунку 4.

Також можна зауважити, що частка імпорту продукції машинобудування у всі роки перевищує питому вагу експорту. Найбільша різниця спостерігалася у 2006 р. - 15,9 \%, а надалі відбувалося зменшення співвідношення. Однак слід зазначити, що значне зниження імпорту продукції машинобудування не призвело до іiі заміщення вітчизняною продукцією, оскільки загальні обсяги іï виробництва в Україні також суттєво знизилися (майже у два рази).

Щодо структури українського експорту машинобудування, то найбільша частка належить металоємним машинам (котли, машини i електричні машини), на які припадає майже $40 \%$. Друге місце займають транспортні засоби, частка яких складає $14,21 \%$, у структурі яких $8,08 \%$ - засоби наземного транспорту [5].

Фахівці пов'язують поточну кризу машинобудівної промисловості із втратою виробничих потужностей на сході країни через проведення АТO, а також зменшенням виробництва їх підприємств-партнерів в інших областях країни. До АТО додалися й інші фактори, такі, як проблеми зі збутом продукції на російський ринок i, звичайно, девальвація гривні $[9$, с. 73]. 


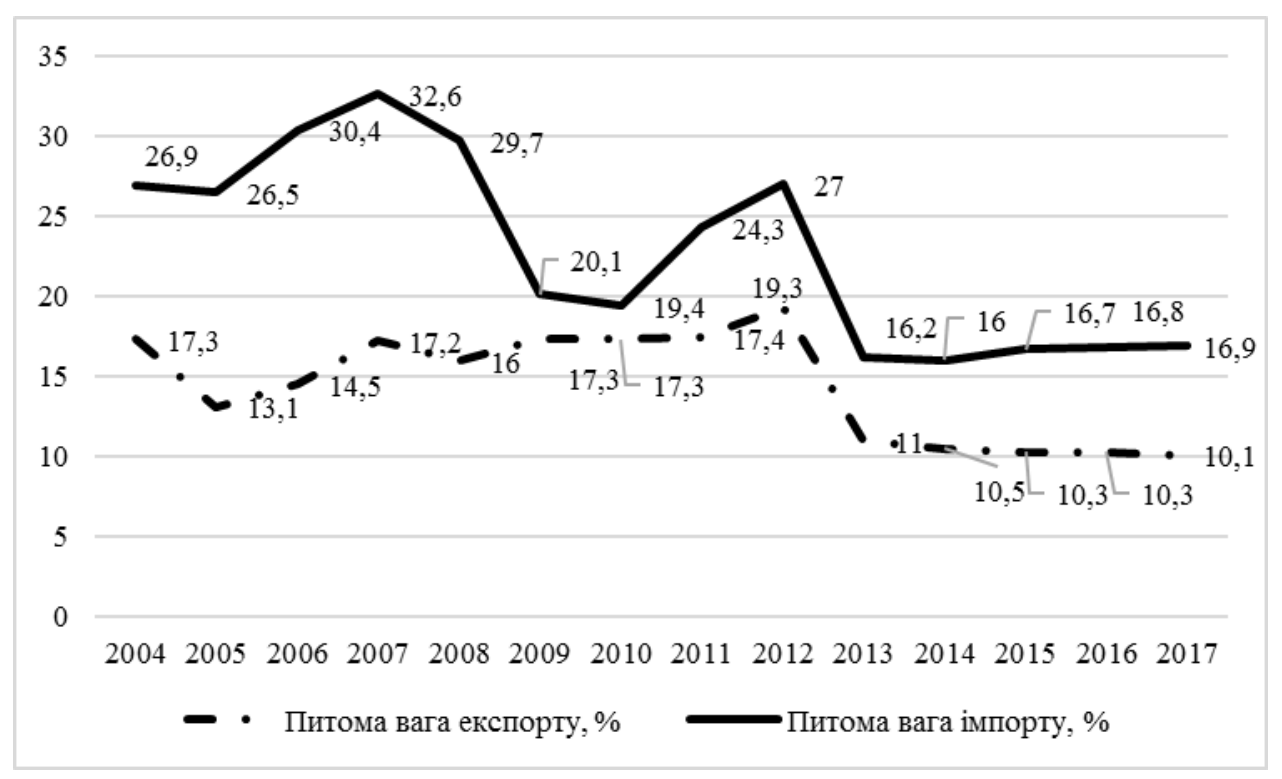

Рисунок 4 - Питома вага експорту та імпорту продукції машинобудування в загальних обсягах українського експорту та імпорту (без урахування тимчасово окупованої території Автономної Республіки Крим, м. Севастополя та зони проведення АТО) $(\%),[2 ; 3]$

Що стосується структури українського імпорту машинобудування, то найбільшу частку охоплюють котли, машини - 42,19 \%, електричні машини $31,78 \%$. Третє місце займають транспортні засоби - 20,56 \%, у структурі яких 19,1 \% - засоби наземного транспорту, крім залізничного (табл. 3.).

Таблиця 3 - Структура експорту-імпорту продукції машинобудування у 2017 році (без урахування тимчасово окупованої території Автономної Республіки Крим, м. Севастополя та зони проведення АТО), \%, [2; 3; 4]

\begin{tabular}{|l|c|c|}
\hline \multicolumn{1}{|c|}{ Види продукції } & Питома вага експорту, \% & Питома вага імпорту, \% \\
\hline $\begin{array}{l}\text { Реактори ядерні, котли, } \\
\text { машини }\end{array}$ & 41,05 & 42,19 \\
\hline Електричні машини & 41,42 & 31,78 \\
\hline Залізничні локомотиви & 4,41 & 0,44 \\
\hline $\begin{array}{l}\text { Засоби крім } \\
\text { транспорту, } \\
\text { залізничного }\end{array}$ & 3,67 & 19,1 \\
\hline Літальні апарати таго апарати & 3,99 & 0,65 \\
\hline Судна та & 2,14 & 0,37 \\
\hline $\begin{array}{l}\text { Прилади } \\
\text { оптичні, фотографічні }\end{array}$ & 3,32 & 5,47 \\
\hline
\end{tabular}


Незважаючи на те, що українська продукція машинобудування експортується до більш ніж 60 країн світу, переважно $\epsilon$ конкурентоспроможною лише на ринках СНД, зокрема Росії, Білорусі, Казахстану. Експортуються здебільшого котли, машини та апарати, електричні машини та устаткування, залізничні та трамвайні локомотиви, шляхове обладнання.

Як свідчать статистичні дані, зібрані у таблиці 4 загальна кількість основних засобів у машинобудівній галузі за останні роки постійно зростає.

Величина введених у експлуатацію засобів виробництва перевищує кількість тих, що вибули, проте їх якісний стан $є$ незадовільним: більша частина матеріальних активів підприємств галузі, мають ступінь зносу більше $50 \%$, тобто більша частина засобів, які використовуються на підприємствах машинобудівної галузі мають низьку ступінь придатності, а це свідчить, що підприємства галузі не можуть випускати високоякісну і висококонкурентну продукцію [8].

Таблиця 4 - Показники руху основних засобів та їх стану у машинобудівній галузі, млн грн [2; 3; 4]

\begin{tabular}{|c|c|c|c|c|c|c|c|}
\hline \multirow[t]{2}{*}{ Роки } & \multirow[t]{2}{*}{ Вартість } & \multicolumn{4}{|c|}{ Pyx } & \multirow{2}{*}{$\begin{array}{l}\text { Залишшкова } \\
\text { вартість }\end{array}$} & \multirow{2}{*}{$\begin{array}{l}\text { Ступінь } \\
\text { зносу, \% }\end{array}$} \\
\hline & & $\begin{array}{c}\text { Введено } \\
\text { у дію }\end{array}$ & $\begin{array}{c}\text { Коефі- } \\
\text { ціснт } \\
\text { введенн } \\
\text { я\% }\end{array}$ & Вибуло & $\begin{array}{c}\text { Коефі- } \\
\text { ціснт } \\
\text { вибуття } \\
\%\end{array}$ & & \\
\hline 1 & 2 & 3 & 4 & 5 & 6 & 7 & 8 \\
\hline 2011 & 50590 & 881 & 1,74 & 554 & 1,09 & 21724 & \\
\hline 2012 & 49567 & 887 & 1,78 & 530 & 1,07 & 20728 & 58,2 \\
\hline 2013 & 54233 & 1265 & 2,33 & 540 & 0,99 & 20956 & 61,4 \\
\hline 2014 & 50544 & 1713 & 3,39 & 592 & 1,17 & 20998 & 58,5 \\
\hline 2015 & 58488 & 1809 & 3,09 & 522 & 0,89 & 22239 & 62,0 \\
\hline 2016 & 56784 & 2042 & 3,59 & 625 & 1,10 & 21354 & 63,5 \\
\hline 2017 & 71395 & 2598 & 3,64 & 792 & 1,11 & 26844 & 65,5 \\
\hline
\end{tabular}

Позитивним моментом є перевищення коефіцієнту введення коефіцієнта вибуття. Але темпи заміни є достатньо низькими, про що свідчить коефіцієнт компенсації вибуття основних засобів, що розраховується як відношення кількості вибулих до введених основних засобів. За нашими розрахунками він складає: $\quad \kappa_{2011}=0,63 ; \quad \mathrm{K \kappa}_{2012}=0,59 ; \quad \kappa_{2013}=0,42 ; \quad \kappa_{2014}=0,34 ; \quad \kappa_{2015}=0,28$; $\mathrm{K}_{2016}=0,30 ; \mathrm{K}_{2017}=0,31$.

За таких умов говорити про високу ефективність роботи галузі вважаємо неможливим.

За офіційними статистичними даними за 2011-2017 роки зроблено оцінку фінансового стану промисловості за допомогою розрахованих 
коефіцієнтів поточної ліквідності, фінансової залежності, рентабельності активів та забезпеченості власними оборотними коштами.

Аналіз здійснених розрахунків, наведених у таблиці 5, показує, що значення показника поточної ліквідності $€$ наближеним до мінімально необхідного нормативного значення.

Таким чином, рівень фінансової безпеки галузі є низьким та потребує змін.

Стосовно кадрового забезпечення машинобудівних підприємств, то слід відзначити, що ситуація також не $\epsilon$ позитивною.

Таблиця 5 - Динаміка окремих показників фінансового стану промислових підприємств України [2; 3; 4]

\begin{tabular}{|c|c|c|c|c|c|c|c|c|}
\hline \multirow[t]{2}{*}{ Коефіціснти } & \multicolumn{7}{|c|}{ Значення коефіціснтів за роками } & \multirow{2}{*}{$\begin{array}{c}\text { Норматив, } \\
\text { тенденція }\end{array}$} \\
\hline & 2011 & 2012 & 2013 & 2014 & 2015 & 2016 & 2017 & \\
\hline $\begin{array}{c}\text { Поточної } \\
\text { ліквідності }\end{array}$ & 1,06 & 1,05 & 1,07 & 1,11 & 1,19 & 1,27 & 1,25 & $1,5-2,5$ \\
\hline $\begin{array}{c}\text { Заборгованос } \\
\text { ті (поточної } \\
\text { залежності) }\end{array}$ & 1,84 & 1,94 & 2,06 & 2,02 & 2,01 & 2,07 & 2,14 & менше 2 \\
\hline $\begin{array}{c}\text { Рентабельніс } \\
\text { ть активів }\end{array}$ & 0,006 & 0,004 & 0,005 & 0,007 & 0,006 & 0,005 & 0,007 & більше 0 \\
\hline $\begin{array}{c}\text { Забезпечення } \\
\text { власними } \\
\text { оборотними } \\
\text { коштами }\end{array}$ & $-0,08$ & $-0,09$ & $-0,09$ & $-0,11$ & $-0,07$ & $-0,09$ & $-0,09$ & більше 0,1 \\
\hline
\end{tabular}

Середньооблікова кількість штатних працівників підприємств машинобудування за період з 2010 по 2017 роки зменшилась, що $\epsilon$ характерним для підприємств промисловості в цілому. Кількість прийнятих як і кількість звільнених працівників за аналізований період в промисловості змінюється прямо пропорційно.

Висновки. Отже, розвиток машинобудівних підприємств супроводжується накопиченням проблем, які негативно на них впливають. Під дією різних факторів розвиток машинобудівної галузі відбувається не прогнозовано, не за планами і програмами, що формуються урядами 3 урахуванням потреб у промисловій продукції й вимог глобалізації світової економіки. Ситуація погіршується із зменшенням проміжків часу між світовими кризами, які негативно впливають на стан національної економіки України. Аналізуючи вищевикладене, та незважаючи на негативні тенденції, які спостерігаються в промисловості і у машинобудуванні, існує впевненість, що вони можуть бути змінені на позитивні. 


\section{Література:}

1. Сейсебаєва Н. Г. Проблеми відновлення виробничого потенціалу підприємств машинобудування. Формування ринкових відносин в Україні : зб. наук. праць. Наук. ред. І. Г. Манцуров. Київ, 2015. Вип. 6 (169). с. 130-133.

2. Офіційний сайт Державної служби статистики України. URL: http://www.ukrstat.org.ua. (дата звернення: 17.10.2017).

3. Аналітична доповідь до Щорічного Послання Президента України до Верховної Ради України «Про внутрішне та зовнішне становище України в 2017 році». Київ : НІСД, 2017. $928 \mathrm{c}$.

4. Постанова Кабінету Міністрів України «Деякі питання визначення середньострокових пріоритетних напрямів інноваційної діяльності загальнодержавного рівня на 2017-2021 роки» від 28 грудня 2016 p. № 1056 URL: http://zakon3.rada.gov.ua/laws/show/1056-2016-\%D0\%BF (дата звернення: 17.10.2017).

5. Чупир О. М. Тенденції розвитку машинобудівного комплексу України: сучасний стан і перспективи. Вісник економіки транспорту і промисловості. 2013. № 43. с. 31-38.

6. Войтко С. В., Анкудович Т. С., Афанасьєва Л. В. Динамічне моделювання складових інноваційної стратегії підприємств машинобудування у забезпеченні сталого розвитку. Вісник Черкаського університету ім. Богдана Хмельницького. Серія: Економічні науки. Черкаси: Видав. відділ ЧНУ, 2012. № 33 (246). с. 3 - 9.

7. Борейко В. Загроза діяльності збиткових підприємств для економіки України. Розвиток національної економіки: методологія та практика: Матеріали міжнародної науково-практичної конференції 15-16 квітня 2014 року, проведеної на базі ДВНЗ «Прикарпатський національний університет імені Василя Стефаника», м. Івано-Франківськ. Тернопіль: Крок, 2014. 285 с. С. 55-57.

8. Шкарлет С. М. Економічна безпека підприємства: інноваційний аспект: монографія. Київ : Книжкове видавництво НАУ, 2007. 436 с.

9. Афанасьєв, Б. В. Економіка підприємств машинобудування України: сучасний стан та перспективи розвитку. Науковий вісник Херсонського державного університету. Серія «Економічні науки», 2014. Вип. 8. Ч. 7. с. 71-74. 